\title{
Water quality variation and screening of microalgal distribution in thachan pond Chidambaram taluk of Tamil nadu
}

\author{
B. Elayaraj and M. Selvaraju * \\ Division of Environmental Science, Department of Botany, Annamalai University, Annamalai Nagar, Tamil Nadu, India - 608002 \\ *Corresponding author E-mail: dr.mselvaraju66@gmail.com
}

\begin{abstract}
A laboratory study was conducted to monitor the water quality and microalgal distribution of Thachan pond, Chidambaram taluk, Cuddalore district, Tamil Nadu, India. The important parameters tested were temperature, $\mathrm{pH}$, turbidity, electric conductivity, total dissolved solids, turbidity, alkalinity, free $\mathrm{CO} 2$, dissolved oxygen, chloride, nitrate and phosphate. Microalgal distribution studies were observed. Monthly fluctuations of different seasonal diversity i.e., 35 algal species belongs to four groups viz., Cyanophyceae (41\%), Chlorophyceae (27\%), Euglenophyceae (14\%) and Bacillariophyceae or Diatoms (17\%). Among the microalgae Cyanophyceae was found to be dominant group throughout in the study period. Microalgae producing biotoxin such as Microcystis aeruginosa, Chroococcus minor, Oscillatoria curviceps, Oscillatoria tenuis, Anabaena spiroides, Nostoc pruniforme and Aphanocapsa grevillei were recorded in the pond. Pond was found to be moderately polluted and showed a trend of increasing eutrophication. The significant correlations were noted in the different parameters.
\end{abstract}

Keywords: Eutrophication, Microalgal Distribution, Pond Water Quality, Seasonal Diversity.

\section{Introduction}

The life is an aquatic ecosystem is directly or indirectly depends on the water quality. Ponds constitute an ecosystem that supports a wide array of organisms ranging from lower plants to higher plants. Water quality can be defined in terms of physical, chemical and biological characterization of water. In some developing countries they are a contributing source of water for domestic use such as washing of cloths, bathing and sometimes as a source of drinking water (Chia et al. 2009). Water supports life on earth and around which the entire fabric of life is woven. Ponds, as sources of water, are of fundamental importance to man. However pond may have been natural water sources exploited by man at different time to meet different needs or may have been created for a multitude of different purposes (Rajagopal et al. 2010). The increased demand for water as a consequence of population growth, agriculture and industrial development has usurped environmentalists to determine the chemical, physical and biological characteristics of natural water resources (Sawant and Telave, 2009).

The distribution and abundance of microalgae in this system are controlled by a wide range of physico-chemical parameters. While microalgae are important primary producers and the basis of the food chain in open water, some species on the other hand can be harmful to human and other vertebrates by releasing toxic substances (hepatotoxins or neurotoxins etc.) into the water. Proliferation of harmful organisms, particularly species should be monitored. Phytoplankton studies and monitoring are useful for control of the physico-chemical and biological conditions of the water in any irrigation project. Therefore certain groups of phytoplankton, especially blue green algae, can degrade recreational value of surface water, particularly thick surface scum, which reduces the use of amenities for contact sports, or large concentrations, which cause deoxygenating of the water leading to fish death (Whitton and Patts, 2000). Over the last few decades, there has been much interest in the processes influencing the development of phytoplankton communities, primarily in relation to physico-chemical factors (Elliott et al. 2002). The algae co-occur even though each species has a specific niche based on its physiological requirements and the constraints of the environment. There are many detailed descriptions of phytoplankton succession being correlated with changes in environmental parameters particularly temperature, light, nutrients availability and mortality factors such as grazing and parasitism.

Tamil Nadu is bestowed with a large number of perennial and temporary ponds. The biodiversity of algal flora in the water bodies shows a correlation with reference to their occurrence and the physico-chemical factors. The algae serve as the primary producers in the food chain and the productivity depends upon the quality of water. Water is a vital resource used for various activities such as drinking, irrigation, fish production, power generation etc. Increased human activities over the last 25 years are imposing a greater stress on these ecosystems resulting in changes in their features. There is a need for scientific management of exploitation and conservation of these natural resources. To achieve this goal there is an urgent need of basic and applied research on various aspects of aquatic ecosystems. In India algal diversity in fresh water wetlands along with their physico-chemical characteristics of the concerned water bodies studies were important. The purpose of this study was to collect sufficient baseline quality data to define current immunological conditions of the pond. This pond, in the urban area, is the main source of water supply for drinking, bathing and for other human activities. The present work is an attempt to explore the microalgal species, their composition along with their logistic correlation with different physico-chemical parameters of the pond water in different seasons during the study period. 


\section{Materials and methods}

\subsection{Study area}

Thachan pond is situated in Mandhakkarai $3 \mathrm{~km}$ near Chidambaram and $5 \mathrm{~km}$ away from Annamalai University. It spreads about approximately $200 \mathrm{~m}$ in length and $150 \mathrm{~m}$ in width The depth of the water ranges from 2 meters to 4 meters in different seasons.

\subsection{Water sample collection and analysis}

In the present study sampling has been done for six months at Thachan pond in Mandhakkarai to study the change in physicochemical characteristics and the microalgal diversity. A periodic collection of water sample has been made on monthly basis from January to June-2014. Samples have been collected in polythene bottles and analysed in the laboratory. An APHA (1992) method was used for water analyses. Physico-chemical parameters such as Temperature, $\mathrm{pH}$, turbidity, electric conductivity, total dissolved solids, total alkalinity, $\mathrm{FCO}_{2}$, dissolved oxygen, chloride, nitrate and phosphate were analysed. Microalgal were photographed using Niken Eclispe Microscope (Nikon Eclipse, 200). The algae were identified using the monographs by Desikachary (1959) for blue green algae and Krishnamurthy (1954) for diatoms.

\subsection{Estimation of phytoplankton}

Water samples were collected from Thachan pond for phytoplankton analysis in black coloured plastic carboys of one litre. Filamentous algae and other floating debris were avoided. For each sample collected, $25 \mathrm{ml}$ of $4 \%$ formaldehyde was added (Welch, 1948) with few drops of Lugol's iodine. Sedimentation was done in glass columns. The sediment was finally reduced to $20 \mathrm{ml}$ and was preserved in a glass vial. From each vial one drop was mounted on a slide and a cover slip was carefully put over it. Five high power fields $(15 \mathrm{X}, 45 \mathrm{X})$, one in each corner of the cover slip and at the centre were made and the algal populations were estimated. These observations were at random and were repeated four times for each sample. This procedure was repeated for each sample and the number of each organism was extra plated to exact number of organism/L (Rao, 1995). Phytoplankton count was done by Lackey's Drop Method (1938) as mentioned in APHA (1985) and modified by Saxena (1987)

\section{Results and discussion}

In the present investigation physico-chemical parameters viz., temperature, $\mathrm{pH}$, turbidity, electric conductivity, total dissolved solids, turbidity, alkalinity, free $\mathrm{CO}_{2}$, dissolved oxygen, chloride, nitrate and phosphate were depicted in the figures. The physicochemical characteristics of water of an aquatic system reflect both the quality of the system and the type and density of its biota. By the analysis of such character, information regarding pollution and extent of pollutant loading of aquatic system may be generated.

\subsection{Temperature $\left({ }^{\circ} \mathrm{C}\right)$}

Temperature is directly related with chemical and biochemical reactions in any aquatic system. The solubility of oxygen has been increased by low temperature. Temperature of surface water in the present study ranged between $29^{\circ} \mathrm{C}-41.1^{\circ} \mathrm{C}$, highest being recorded in May (Figure 1). Shinde et al. (2011) and Sharma et al. (2007) observed maximum temperature in summer and minimum in post monsoon. A similar study was made by Mahesh et al. (2013) and Javaid and Ashok (2012).

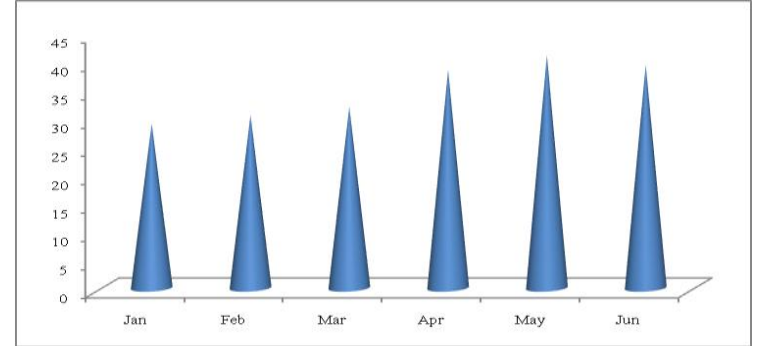

Fig. 1: Seasonal Variation of Temperature ${ }^{\circ} \mathrm{c}$

\section{2. $\mathrm{pH}$}

Hydrogen ion concentration $(\mathrm{pH})$ is closely related to free $\mathrm{CO}_{2}$ complex which during present study ranged between 6.9-8.5. $\mathrm{pH}$ is controlled by the carbon dioxide bicarbonate- carbonate equilibrium system (Figure 2). High rate of photosynthetic activity increases the $\mathrm{pH}$ due to consumption of $\mathrm{CO}_{2}$ in this process (Harney et al. 2013).

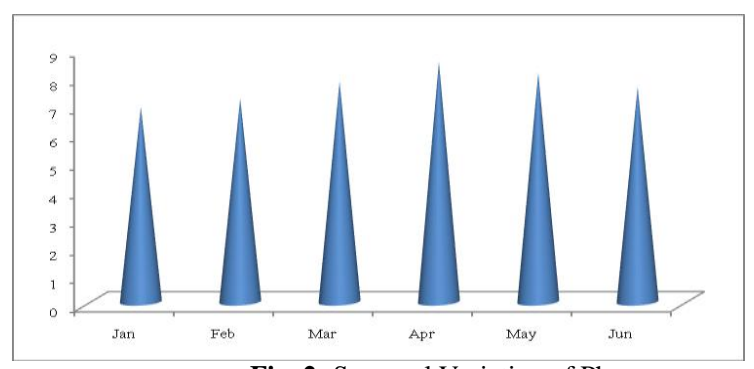

Fig. 2: Seasonal Variation of $\mathrm{Ph}$

\subsection{Turbidity (NTU)}

Turbidity ranged between 49-61.9 NTU. It was minimum in summer and maximum in post monsoon months (Figure 3). The similar type of results were given by Khanna (1993) and Khanna and Bhutiani (2003). Turbidity is an important physical parameter which has a significant bearing on productivity of aquatic ecosystem (Rave et al. 2012). The particulate matter like clay, silt, colloidal particles, algal blooms, debris and the other microscopic organisms are responsible for turbidity in water. Turbidity directly affects the productivity of surface water because scatter and absorption of light in water depends upon turbidity.

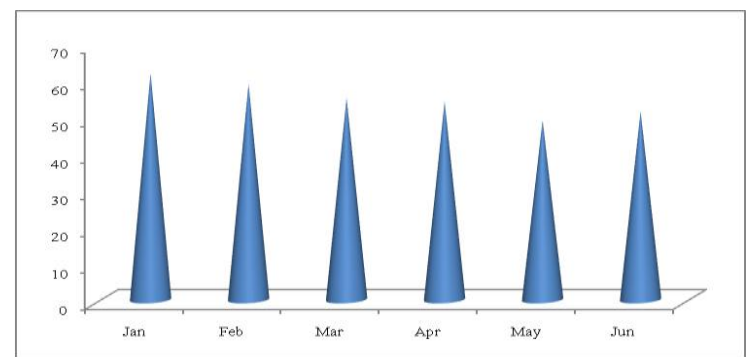

Fig. 3: Seasonal Variation of Turbidity (NTU)

\subsection{Electrical conductivity $(\mu S)$}

Electrical conductivity of water is a numerical expression of the ability of water sample to carry an electric current. It depends on the nature and concentration of ionized substances or electrolytes dissolved in water. Electrical conductivity values ranged between 462.1-582 $\mu \mathrm{S}$ (Figure 4). A sudden rise in conductivity in water during post monsoon and monsoon season indicates addition of some pollutants (Trivedy and Goel, 1984). 


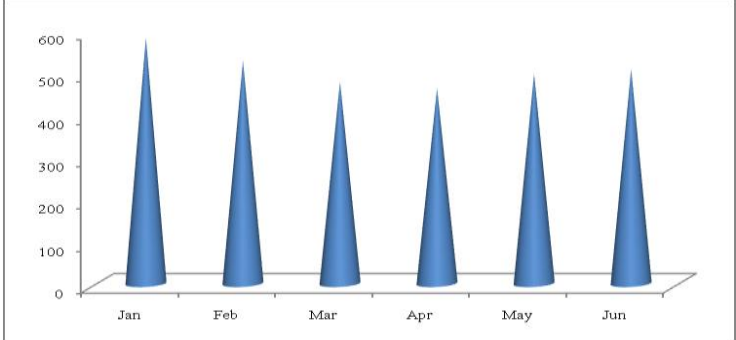

Fig. 4: Seasonal Variation of Electrical Conductivity ( $\mu \mathrm{s})$

\subsection{Total dissolved solids (mg/l)}

Total dissolved solids of sample waters ranged between 212-380 mg1 (Figure 5). Total dissolved solids composed mainly of carbonates, bicarbonates, chlorides, sulphates, phosphates and nitrates. Higher content of total dissolved solids adversely affects the plants by increasing salinity of the soil. The wastes from inhabitations of the pond enhance total dissolved solids of water of pond. Total dissolved solids might be due to accumulation of the anthropogenic activity which hampered the quality of water (Senthilkumar and Sivakumar, 2008) and growth of diatoms.

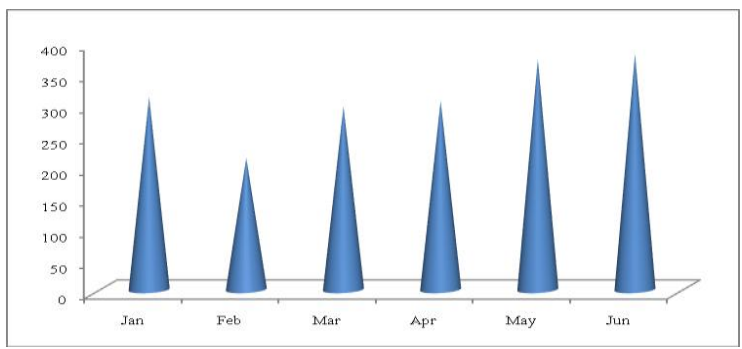

Fig. 5: Seasonal Variation of Total Dissolved Solids (Mg/L)

\subsection{Total alkalinity (mg/l)}

Total alkalinity varied from $64.9-99.6 \mathrm{mg} 1$. It is closely related to free carbon dioxide (Figure 6). It is formed due to dissolution of $\mathrm{CO} 2$ in water. The range of total alkalinity in Indian waters may be found between $40 \mathrm{mg} \mathrm{l}^{-1}$ to over $1000 \mathrm{mg} \mathrm{l}^{-1}$ (Rajyalakshmi et al. 1998). Dwivedi and Pandey (2002) reported that the total alkalinity of water was maximum during summer and gradually decreased during pre-monsoon season and reached its lowest values during monsoon season. Lashari et al. (2009) and Shinde et al. (2011) reported that the values of total alkalinity were more in summer when compared to other seasons.

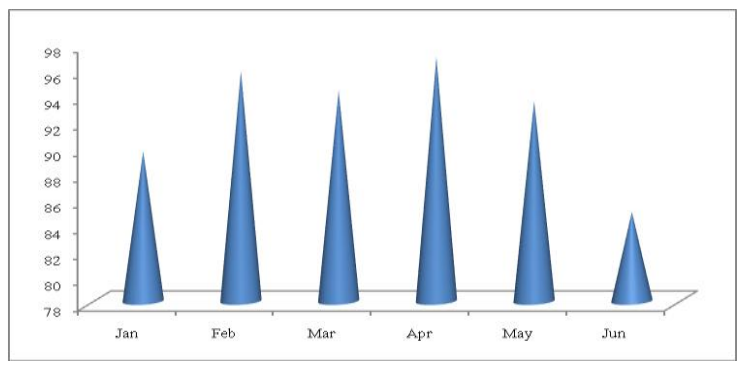

Fig. 6: Seasonal Variation of Total Alkalinity $(\mathrm{Mg} / \mathrm{L})$

\subsection{Free carbon dioxide (mg/l)}

Free carbon dioxide enters into chemical combination of aquatic system to form carbonates and bicarbonates. It assimilates carbon and incorporates into the skeleton of aquatic autotrophs. The concentration of free $\mathrm{CO}_{2}$ significantly varied from $34.0-72.1 \mathrm{mg} /$ (Figure 7). At high temperature during summer and post monsoon seasons the high rate of decomposition of organic matter, resulted in release of $\mathrm{FCO}_{2}$ in surface water (Yadav et al. 1987). Dwivedi and Pandey (2002), the minimum range of carbon dioxide is in post monsoon season and this is due to the higher photosynthetic activities of phytoplankton.

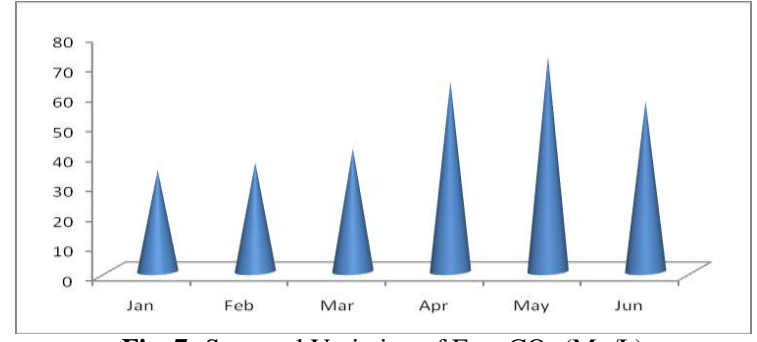

Fig. 7: Seasonal Variation of Free $\mathrm{CO}_{2}(\mathrm{Mg} / \mathrm{L})$

\subsection{Dissolved oxygen (mg/l)}

Dissolved oxygen is required for many physical and biological processes prevailing in water. The oxygen supply in water comes by diffusion from the air and from photosynthesis by aquatic plants. Dissolved oxygen affects the solubility and availability of many nutrients and therefore productivity of aquatic ecosystem (Wetzel, 1983). During the present investigation, DO concentration varied from 9.0-14.8 mg1. Highest value (14.8 mg1) recorded during January may be due to low temperature of water during post monsoon season (Figure 8). During monsoon and post monsoon the level of dissolved oxygen was quite satisfactory, perhaps due to good aeration caused by rain water as reported earlier by Rekha Rani et al. (2004). Low content of dissolved oxygen is due to indiscriminate use of pond by local people and higher decomposition of organic matter with increase in temperature of water.

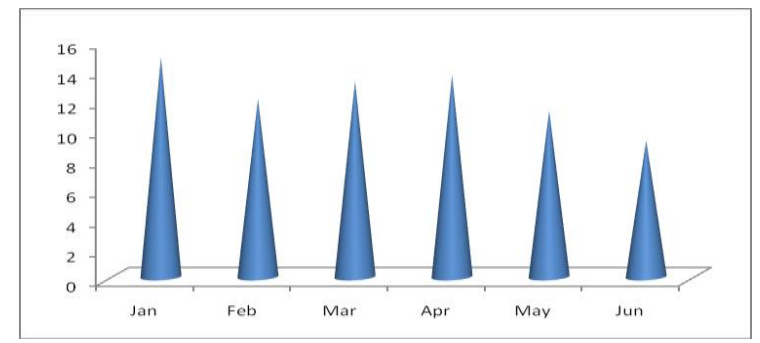

Fig. 8: Seasonal Variation of Dissolved Oxygen $(\mathrm{Mg} / \mathrm{L})$

\subsection{Chloride (mg/l)}

Chloride values ranged between 169.96-224.97 mg1. High chloride concentration during February may be due to direct mixing of cattle dung and human excreta to pond water (Figure 9). Increases in chloride value from earlier values of Nayak (1997) reflect magnitude of organic waste decomposition in pond water. The chloride contents normally increases as the mineral contents increases (Dubey, 2003).

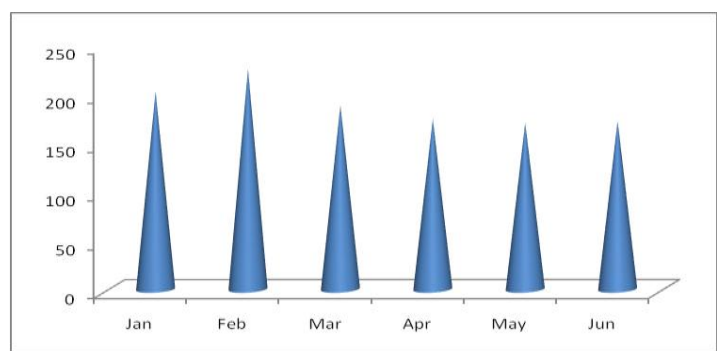

Fig. 9: Seasonal Variation of Chloride $(\mathrm{Mg} / \mathrm{L})$

\subsection{Nitrate and phosphate (mg/l)}

Nitrate content is excellent parameters to judge organic pollution and it represents the highest oxidized form of nitrogen. The nitrates are an important source of nitrogen for phytoplankton. Nitrate-nitrogen in the present study varied from $0.245-0.377 \mathrm{mg} 1$. It is used by plants during their growth and utilized in the synthesis of organic nitrogenous compounds (Figure 10). 


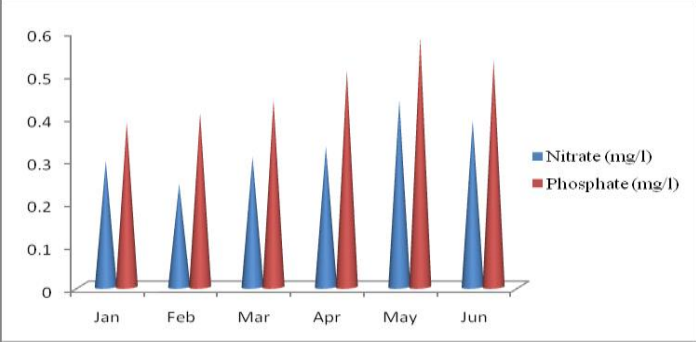

Fig. 10: Seasonal Variation of Nitrate and Phosphate $(\mathrm{Mg} / \mathrm{L})$

Phosphorus occurs naturally in rocks and other mineral deposits. During the natural process of weathering, the rocks gradually release the phosphorus as phosphate ions which are soluble in water. Phosphate-phosphorous values varied from 0.284-0.685 mg1. In the present investigation, high values of phosphate during summer seasons may be due to rapid evaporation and mineralization of decomposed materials in pond water. Harney et al. (2013) reported the maximum Nitrate and phosphate during summer and minimum during post monsoon in Pindavani Pond of Central India.

\subsection{Phytoplankton community}

Microalgal species belonging to Cyanophyceae, Chlorophyceae, Euglenophyceae and Bacillariophyceae or Diatoms groups were recorded in Thachan pond during the study period (Table 1). In the present investigation 35 species were identified, out of which 14 genera belongs to Cyanophyceae $(41 \%), 9$ of Chlorophyceae (27\%), 5 of Euglenophyceae (14\%) and 7 of Bacillariophyceae or diatoms (17\%) in pond respectively (Figure 11). It was found that cyanophyceae was the dominant group in the pond.

$\square$ Cyanophyceae $\mathbf{\square}$ Chlorophyceae $\square$ Euglenophyceae $\square$ Bacillariophyceae

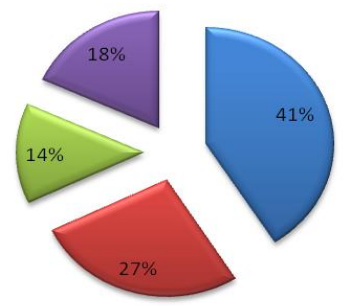

Fig. 11: Percentage (\%) Of Microalgal Distribution in Thachan Pond

\subsubsection{Cyanophyceae}

Cynophyceae are well known to occur in diverse physicochemical conditions with varying degree of abundance and can tolerate wide fluctuations in chemical factors. The maximum number of cyanophyceae was observed in the month of January, February and June the low density was noticed in the month of April and May. Among the cyanophytes Microcystis aeruginosa, Chroococcus minor, Oscillatoria curviceps, Oscillatoria tenuis, Anabaena spiroides, Nostoc pruniforme and Aphanocapsa greville $i$ was the dominant species in the study period.

Table 1: Microalgal Distribution in the Water Sample of Thachan Pond during the (January to June-2014)

\begin{tabular}{|c|c|c|c|c|c|c|c|}
\hline \multirow{2}{*}{ Sl. No } & \multirow{2}{*}{ Name of the Species } & \multicolumn{6}{|c|}{ Months-2014 } \\
\hline & & Jan & Feb & Mar & Apr & May & Jun \\
\hline & Cyanophyceae & & & & & & \\
\hline 01 & Microcystis aeruginosa (Wittr.) Kirchner & + & + & + & + & + & + \\
\hline 02 & Chroococcus minor (Kutz.) Nageli & + & + & + & + & + & + \\
\hline 03 & Lyngbya shackletoli West & + & - & - & - & - & + \\
\hline 04 & Oscillatoria curviceps Ag. ex Gomont & + & + & + & + & + & + \\
\hline 05 & Oscillatoria subbrevis Schmidle F. Crassa & - & + & + & - & - & - \\
\hline 06 & Spirulina major (Kütz.) Gomont & + & + & + & + & - & + \\
\hline 07 & Spirulina princeps Voucher ex. Gomont & + & + & - & - & - & - \\
\hline 08 & Anabaena spiroides Klebahn & + & + & + & + & - & + \\
\hline 09 & Nostoc pruniforme Ag. & + & + & + & + & + & + \\
\hline 10 & Oscilltoria tenuis Ag. Ex Gomont & + & + & + & + & + & + \\
\hline 11 & Merismopedia minima Beck & + & + & + & + & - & - \\
\hline 12 & Chroococcus disperses (V. Keissler) Lemm. & + & - & - & - & - & + \\
\hline 13 & Chroococcus minor (Kutz.) Nageli & + & + & + & - & - & + \\
\hline 14 & $\begin{array}{l}\text { Aphanocapsa grevillei (Hass.) Rabenh } \\
\text { Chlorophyceae }\end{array}$ & + & + & + & + & + & + \\
\hline 15 & Chlamydomonas globosa Snow. & + & + & + & + & + & + \\
\hline 16 & Palmella miniata Lieb. & + & + & + & + & + & + \\
\hline 17 & Chlorella pyrenoidosa Chick & - & - & + & + & - & + \\
\hline 18 & Chlorella vulgaris Beyernick & + & + & + & - & - & - \\
\hline 19 & Scenedesmus accuminatus Kutz. & - & - & + & - & - & + \\
\hline 20 & Scenedesmus quadricauda (Turp.) Breb. & + & + & + & + & - & - \\
\hline 21 & Cladophora crispate (Roth) Kutz. & - & - & - & - & - & + \\
\hline 22 & Spirogyra sps. & + & + & + & + & + & + \\
\hline 23 & $\begin{array}{l}\text { Closterium purvulum Nageli } \\
\text { Euglenophyceae }\end{array}$ & + & + & + & + & + & + \\
\hline 24 & Euglena viridis Ehr. & + & + & + & + & + & + \\
\hline 25 & Euglena convolute Korsch & + & - & - & + & - & + \\
\hline 26 & Euglena oxyuris fo. Maior & + & + & - & - & - & + \\
\hline 27 & Euglena elastica Presc & + & - & - & + & + & - \\
\hline 28 & $\begin{array}{l}\text { Euglena spirosura var. fusca } \\
\text { Bacillariophyceae or Diatoms }\end{array}$ & + & + & + & + & + & + \\
\hline 29 & Cyclotella meneghiniana Kutz. & + & + & + & + & + & + \\
\hline 30 & Actinella punctanta Lewis & + & + & + & + & + & + \\
\hline 31 & Amphora ovalis Kutz. & + & + & + & - & - & + \\
\hline 32 & Diatoma sps. & + & + & + & + & + & + \\
\hline 33 & Navicula cincta Kutz. & - & - & + & - & - & + \\
\hline 34 & Navicula peregrina Kutz. & + & + & - & - & - & + \\
\hline 35 & Pinnularia borealis Her. & - & - & - & + & - & - \\
\hline
\end{tabular}

$(+)=$ Present, $(-)=$ Absent. 


\subsubsection{Chlorophyceae}

Chlorophyceae are free living and planktonic, mostly confined to shallow water and are attached to the submerged plants or found in moist soil (Huisman et al. 2005). This group was represented by nine species and the maximum density of Chlorophyceae was observed in the month of January, March and July and minimum number was noticed in the month of May respectively. Sommer $e t$ al. (1986) reported that maximum abundance of Chlorophyceae was in post monsoon months.

\subsubsection{Euglenophyceae}

In the present study the Euglenophyceae comprising of five species belonging to two genera were recorded in all seasons in Thachan pond. The maximum density of Euglenophyceae was observed in the month of January and minimum was noticed in the month of March.

\subsubsection{Bacillariophyceae}

Bacillariophyceae or Diatoms were represented by seven species out of these four species belonging to three genera were recorded in all seasons. Diatoms are considered to be the best indicators of quality and tropic status of the water body (Callieri, 2008). Temperature and $\mathrm{pH}$ will play key role in the distributions of diatoms and abundance of diatoms will be more in colder months. The maximum abundance of diatoms was encountered in the post monsoon season and low was noticed in summer season. Present findings are agreeable with earlier reports (Sommer et al. 1986). Goel et al. (1992) have stated that Bacillariophyceae occurs in all types of waters. Navicula and Cyclotella indicate pollution in the present water body that occurred commonly.

Maximum numbers of algal species were recorded for the site of sewage discharge and supported the earlier observations that the water bodies influenced by domestic sewage effluent are most conductive to luxuriant growth of plankton which form nuisance blooms of blue green algae (Tripathi and Pandey, 1990). Based on their distribution at the pond algae may be categorized in pollution tolerant and pollution sensitive species. Microcystis aeruginosa, Chroococcus minor, Anabaena spiroides, Nostoc pruniforme, Oscillatoria sp. (all cyanophyceae) Chlamydomonos, Spirogyra sp. Palmella miniata (all chlorophyceae) and Cyclotella meneghiniana, Actinella punctanta, Diatoma sp., (bacillariophyceae) were found to toxin producing algal species (Palmer, 1980; Duncan et al. 2000).

\section{Conclusion}

It was observed that Microcystis aeruginosa, Chroococcus minor, Oscillatoria curviceps, Oscillatoria tenuis, Anabaena spiroides, Nostoc pruniforme and Aphanocapsa grevillei are most abundant species throughout the study physico-chemical analyses of water sample from the Thachan pond indicate that all the pollution parameters, show values towards higher side for a typical freshwater pond. More research work is required for an assessment of human gastro-intestinal cancers with chronic consumption of cyanophytes in drinking water. The present work shows that parameters like $\mathrm{pH}$ alkalinity and conductivity are within the permissible limits. However, parameters like dissolved oxygen, temperature and turbidity are above the permissible limits for drinking purposes as prescribed by the European Commission and all the physico-chemical parameters appeared within manageable levels and distribution of phytoplankton. If the pond is properly maintained in future, then it will be free from eutrophication.

\section{Acknowledgement}

This work was carried out with the help of financial support provided by University Grants Commission. Grant F. No. 41411/2012 (SR) Dated: 16-07-2012 for funding the project - New Delhi. Author is also grateful thanks to Head, Department of Botany, Annamalai University, Annamalai Nagar, Tamil Nadu, India, for giving a good support and laboratory facility for this research work.

\section{References}

[1] APHA (1985), Standard methods for the examination of waste water. American Public Health Association. Wasington. D.C.

[2] APHA (1992), Standard methods for the examination of waste water, $18^{\text {th }}$ edn. American Public Health Association, New York.

[3] Callieri C (2008), Picophytoplankton in freshwater ecosystems: the importance of small-sized phototrophs. Freshwater Reviews 1, 1-28 http://dx.doi.org/10.1608/FRJ-1.1.1.

[4] Chia AM, Abolude DS, Ladan Z, Akanbi O \& Kalaboms A (2009), The presence of Microcystins in aquatic ecosystems in northern Nigeria: Zaria as a case study. Research Journal of Environmental Toxicology 3, 170-178 http://dx.doi.org/10.3923/rjet.2009.170.178.

[5] Desikachary TV (1959), Cyanophyta: Monographs on Algae. ICAR New Delhi, India. 686pp.

[6] Dwivedi BK \& Pandey GC (2002), Physico-chemical factors and algal diversity of two ponds (Girijakund and Maqbara pond) faizabad, India. Pollution Research 21(3), 361-370.

[7] Dubey N (2003), A comparative status of quality of drinking water of Bhopal city filtration plants and ground water with special reference to heavy metals and organo chemical, Ph.D. Thesis, Barkatullah University, Bhopal.

[8] Duncan JB, Kenneth WK, Ronald AH, Xuan H \& Fun SC (2000), Assessment potential health risk from microcystin toxins in blue green algae dietary supplements. Environmental Health perspective 108(1), 435-439.

[9] Elliott JA, Irish AE \& Reynolds CS (2002), Predicting the spatial dominance of phytoplankton in light limited and incompletely mixed eutrophic water column using the Protech model. Fresh water Biology 47, 433-440 http://dx.doi.org/10.1046/j.1365-2427.2002.00813.x.

[10]Goel PK, Kulkarni AY, Katavakar SD \& Trivedy RK (1992), Studies on diurnal variation in some physicochemical characteristics and phytoplankton of freshwater polluted pond. Indian Journal of Environmental Protection 12(97), 503-508.

[11]Harney NV, Dhamani AA \& Andrew RJ (2013), Seasonal variations in the Physico-chemical parameters of Pindavani pond of Central India. Weekly Science 1(6), 1-8.

[12]Huisman J, Matthijs HCP \& Visser PM (2005), Harmful Cyanobacteria. In: Springer Aquatic Ecology Series 3. Springer, Dordrecht, The Netherlands. 243pp.

[13]Javaid AS \& Ashok KP (2012), Physico-chemical characteristics of water in Wular Lake-a Ramsar site in Kashmir Himalaya. International Journal of Geology, Earth and Environmental Sciences Vol. 2(2), 257-265.

[14]Khanna DR (1993), Ecology and pollution of river Ganga, Athish Publishing House, Delhi. 1-241pp.

[15] Khanna DR \& Bhutiani R (2003), Ecological status of Sitapur pond at haridwar (Uttarachal), India. Indian Journal of Environment and Ecoplanning 7(1), 175-178.

[16]Krishnamurthy V (1954), Ecology and Seasonal Succession of the algal flora of a salt marsh at Madras. Journal of Madras University, $B$ 24: 161-178.

[17]Lackey JB (1938), Public Health Reports 53, 2080-2093 http://dx.doi.org/10.2307/4582717.

[18]Lashari KH, Korai AL, Sahato GA \& Kazi TG (2009), Limnological Studies of Keenjhar Lake, District, Thatta, Sindh, Pakistan. Pakistan Journal of Analytical and Environmental Chemistry 10(1), 39-47.

[19] Mahesh K, Mishra, Neeta Mishra \& Devendra NP (2013), An assessment of the physicochemical characteristics of Bhamka pond, Hanumana, Rewa district, India. International Journal of Innovative Research in Science, Engineering and Technology 2(5), 1781-1788

[20]Nayak M (1997), Study on Bio-chemical changes in some aquatic macrophytes growing in different ecological conditions at Bhagalpur. Ph.D. thesis, Bhagalpur University, Bhagalpur.

[21] Palmer CM (1980), Algae and water pollution, Castle House publication. London. 123pp. 
[22]Rajagopal T, Thangamani A \& Archunan G (2010), Comparison of physico-chemical parameters and phytoplankton species diversity of two perennial ponds in Sattur area, TamilNadu. Journal of Environmental Biology 31(5), 784-794.

[23]Rajyalakshmi T, Mohanty AN, Ravichandran P \& Pillai SM (1988), The soil and water characteristics of confined brackish water ponds of Chilka lake fringe area. In Proc. First Indian Fisheries Forum, AFS, Mangalore, India 125-128.

[24]Rao VR (1995), In Fauna of Chilka lake. Wetland Ecosystem Series 1. 2001. Survey of India, 673pp.

[25]Rave RS, Sharma R, Sisodiya MK, Sharma PK, Sharma RK \& Sharma P (2012), A study on monthly variation in physico-chemical and biological characteristics of Meetha pond, dewas (M.P.) India. Asian Journal of Biochemical and Pharmaceutical Research 3(2), 206-214.

[26]Rekha Rani, Gupta BK \& Shrivastava KBL (2004), Studies on water quality assessment Madhya Pradesh: Seasonal Parametric variations. Nature Environment and Pollution Technology 3(4), 563-565.

[27] Sawant RS \& Telave AB (2009), Seasonal variations in physicochemical characteristics of four aquatic ecosystems in Gadhinglaj Tahsil of Maharashtra. Nature Environment and Pollution Technology 8(3) 509-514.

[28]Saxena, MR (1987), Environmental Analysis. Water, Soil and Air Agro Botanical Publishers (India) 15-120.

[29]Senthilkumar R \& Sivakumar K (2008), Studies on phytoplankton diversity in response to abiotic factors in Veeranam lake in the Cuddalore district of Tamil Nadu. Journal of Environmental Biology 29, 747-752.

[30]Sharma KK (2007), Some immunological investigations in Ganga stream, katra. Jammu \& Kashmir state Aquatic Biology 22(1), 105 109.

[31] Shinde SE, Pathan TS, Raut KS \& Sonawane DL (2011), Studies on the Physico-chemical parameters and Correlation Coefficient of Harsool-savangi Dam, District Aurangabad, India. Middle-East Journal of Scientific Research 8(3), 544-554.

[32]Sommer U, Gliwiez ZM \& Lampert W (1986), The PEG-model of seasonal succession of planktonic events in freshwaters. Archiv für Hydrobiologie 106: 433-471.

[33]Tripathi AK \& Pandey SN (1990), Water pollution. Ashish Publication House, New Delhi. 326pp.

[34]Trivedi MK \& Goel PG (1984), Chemical and biological methods for pollution studies. Environmental Publication, Karad, 247pp.

[35] Welch PS (1948), Limnological methods. Mc. Graw - Hill Book Co. Inc; New York. 381pp.

[36]Wetzel RG (1983), Limnology. Second edition Saunders College Publishing, U.S.A. 767pp.

[37]Whitton BA \& Potts M (2000), The Ecology of Cyanobacteria. Kluwer Academic Publishers, Netherlands.

[38] Yadav YS, Singh RK \& Kalekar V (1987), Limnology and productivity of Dilghali Bhel (Assam), India. Tropical Ecology 28, 137-147. 